\title{
INSULIN-LIKE GROWTH FACTOR BINDING PROTEIN-1, NON-ALCOHOLIC FATTY LIVER DISEASE, AND ITS RELATIONSHIP WITH FRUCTOSE CONSUMPTION IN CHILDREN WITH OBESITY
}

\author{
Anaisa G. Flores-RamíreZ ${ }^{\ddagger}$, Lorena del R. IBARRA-Reynoso ${ }^{\ddagger}$, Hilda Lissete López-Lemus, \\ Montserrat Olvera-Juárez, Claudia luevano-Contreras and Ma. Eugenia Garay-Sevilla* \\ Department of Medical Sciences, Division of Health Science, University of Guanajuato, Campus León, \\ Guanajuato, Mexico. \\ ‡These authors contributed equally to this study.
}

\begin{abstract}
Background: Over consumption of added sugar is associated with obesity, non-alcoholic fatty liver disease (NAFLD), and insulin resistance (IR). Objective: The objective of the study was to study the insulin-like growth factor binding protein-1 (IGFBP-1) and NAFLD and their relationship with fructose consumption in children with obesity. Methods: A cross-sectional study was carried out in children 6-11 years old with obesity. Anthropometric measurements, fructose consumption, glucose, lipid profile, insulin, and IGFBP-1 levels were evaluated; the homeostatic model assessment of IR (HOMA-IR) was used. NAFLD was evaluated by ultrasound. Results: We studied 83 children with a mean age of $9.2 \pm 1.3$ years. About $93 \%$ of the girls presented IR and lower levels of IGFBP-1 $(p=0.0001)$. The group with the lower levels of IGFBP-1 had higher HOMA-IR ( $p=0.000002)$; IGFBP-1 was associated with fructose consumption $(r=-0.25 ; p=0.03$ ), body mass index (BMI) $(r=-0.42 ; p=0.02)$, and HOMA-IR $(r=-0.61 ; p=0.002)$. About $81 \%$ of the children were classified as having mild or moderate/severe NAFLD, and these groups had higher HOMA-IR $(p=0.036)$ and fructose consumption $(p=0.0014)$. Conclusions: The girls had more metabolic alterations. The group with lower levels of IGFBP-1 (hepatic IR) was associated with higher BMI, HOMA-IR, and fructose consumption; the group with higher severity of NAFLD showed higher HOMA-IR and fructose consumption. (REV INVEST CLIN. 2019;71:339-48)
\end{abstract}

Key words: Fructose intake. Children. Obesity. Insulin resistance. Non-alcoholic fatty liver disease.

Corresponding author:

*Ma. Eugenia Garay-Sevilla

20 de Enero, 929

Col. Obregón

C.P. 37000, León, Guanajuato, México

Received for publication: 13-02-2019

E-mail: marugaray_2000@yahoo.com

Approved for publication: 22-05-2019

DOI: $10.24875 / R I C .19002995$ 


\section{INTRODUCTION}

The prevalence of childhood obesity continues to grow worldwide ${ }^{1}$. Increased sugar consumption is considered to be a contributor to the global epidemics of obesity and diabetes and their associated cardiometabolic risks ${ }^{2}$. Overconsumption of added sugar is associated with obesity, non-alcoholic fatty liver disease (NAFLD), and insulin resistance (IR) $)^{3-5}$. Some of these associations may be the result of hepatic de novo lipogenesis stimulation by dietary sugars ${ }^{6,7}$. Among added sugars, fructose is emerging as a potentially harmful component ${ }^{7,8}$. The intake of large amounts of fructose creates an unregulated source of carbon precursors for hepatic lipogenesis ${ }^{9}$, which contributes to the development of NAFLD ${ }^{10}$ and hepatic $\mathbb{I R}^{9,11}$. Hepatic IR is characterized by an inability of insulin to suppress glycogenesis and glycogenolysis, and it is closely associated with a dysfunction of the adipose tissue ${ }^{12}$. The liver has been shown to be the main site of production of the insulin-like growth factor binding protein-1 (IGFBP-1) in humans, which has been proposed as a hepatic insulin-resistance marker ${ }^{13,14}$. IGFBP-1 is unique among other hepatic insulin-resistance markers because it is regulated by insulin and predicts glucose tolerance worsening; moreover, it is less labile than insulin ${ }^{13,15}$. Since IGFBP-1 is inversely correlated with liver fat, it is independent of obesity. Hepatic fat accumulation is tightly linked to hepatic IR and is characterized by a decreased ability of insulin to suppress hepatic glucose and triglyceride (TG)-rich, very-low-density-lipoprotein particle production in the liver ${ }^{14}$. On the other hand, one of the weaknesses of IGFBP-1 is that its reproducibility in serum, such as other indicators of $I R$, has been reported to decline with deteriorating glucose tolerance ${ }^{13}$. Previous research has shown that IGFPB-1 promotes the regeneration of $\beta$ cells $^{16}$ and that high levels of IGFBP-1 are associated with a reduction in diabetes risk ${ }^{15,17}$. Low serum IGFPB-1 levels have also been observed in obesity, hyperinsulinemic conditions ${ }^{18,19}$, and NAFLD conditions ${ }^{20}$. A previous study in children with obesity in our group showed that $73.1 \%$ had a high homeostatic model assessment of IR (HOMA-IR) and low IGFBP-1 levels, which could be an indication of whole-body IR and hepatic $\mathbb{I R}^{21}$.

Few studies have been conducted in children, and to the best of our knowledge, there are no studies evaluating hepatic IR, NAFLD, and fructose consumption in children with obesity. Therefore, the aim of this study was to evaluate IGFBP-1 (used as a marker of hepatic IR), NAFLD and their relationship with fructose consumption in children with obesity.

\section{METHODS}

\section{Study design and population}

A cross-sectional study was performed in children with obesity. Children 6-11 years old and attending schools in the city of Leon, Mexico, were invited to participate in the study. A total of 83 children with obesity, clinically healthy and without nutritional treatment were included. A sample size was calculated according to the correlation between IGFBP-1 and body mass index (BMI) found by Reinehr et al. ${ }^{22}$, considering a power of $80 \%$ and an alpha of two sides of 0.01 , obtaining a sample size of 68 participants. However, it was decided to increase the sample size by $20 \%$, and 83 participants were included.

Anthropometric measures such as weight, height, and waist circumference were taken using a Tanita HD357 scale, a Seca 406 stadiometer, and a Lufkin measuring tape ${ }^{23}$. The weight and height were used to calculate BMI (weight/height ${ }^{2}$ ). Children were considered as having obesity if their BMl after adjustment for gender and age, were higher than the adult equivalent of $30 \mathrm{~kg} / \mathrm{m}^{2}$, according to the international tables of Cole et al. ${ }^{24}$. Blood pressure was measured using a mercury sphygmomanometer according to the National High Blood Pressure Education Program Working Group ${ }^{25}$.

\section{Biochemical measurements}

A venous blood sample was obtained after $12 \mathrm{~h}$ of fasting to measure glucose by an enzymatic method (Lakeside, Mexico City, Mexico). TGs and cholesterol were also measured by the enzymatic method (Spinreact, Girona, Spain). Serum aliquots were stored at $-80^{\circ} \mathrm{C}$ until the further determination of IGFPB-1, measured by enzyme-linked immunosorbent assay (ELISA, Mediagnost, Reutlingen, Germany), and insulin, by radioimmunoassay ( $\mathrm{CisBio}^{\circledR}$ ). For IGFPB-1, only 68 samples were processed due to insufficient serum. 
The intra- and inter-assay variation coefficients for IGFPB-1 were $6.2 \%$ and $7.4 \%$, and for insulin, they were $2.7 \%$ and $5.8 \%$, respectively. There are no studies defining cutoff values for IGFPB-1; therefore, for this study, a low IGFBP-1 level was considered as $\leq$ $6.67 \mathrm{ng} / \mathrm{mL}$ and a high level was > $6.67 \mathrm{ng} / \mathrm{mL}$, according to our previous work ${ }^{21}$.

Whole IR was calculated with HOMA-IR according to Matthews et al. ${ }^{26}$, and children were classified as having IR according to cutoff values from previous work in Mexican population ${ }^{27}$. The TG/high-density lipoprotein cholesterol index (I-TG/HDL-C) was calculated, which is an indirect method for IR proposed by Quijada et al. ${ }^{28}$, and values $>2.0$ were considered as a cardiovascular risk factor ${ }^{29}$.

\section{Nutritional assessment}

Each child completed a 24-h dietary recall (2 during the week and 1 on the weekend) with the help from their parents. Quantification of macronutrients (proteins, lipids, and carbohydrates) was carried out using the software Food Processor $2015^{\circledR}$. The total fructose intake was calculated according to the fructose of foods, called free fructose, and the fructose released from sucrose during digestion, using the formula $($ total fructose $=$ free fructose $[\mathrm{g} /$ day $]+1 / 2$ free sucrose $[\mathrm{g} /$ day $])^{30}$. Additional analysis by food groups rich in fructose was carried out to detect which one had a major contribution to total fructose intake. The food groups analyzed were five: vegetables, fruit, $100 \%$ fruit juice, sugar-sweetened foods, and sugar-sweetened beverages ${ }^{30}$. Once the results were obtained, the average consumption was calculated from the three dietary recalls.

\section{Ultrasonographic evaluation of NAFLD}

NAFLD was assessed by ultrasound using a General Electric Logic 400 MD (General Electric, Boston, MA, USA) with a convex transducer of $3.6 \mathrm{MHz}$. The ultrasonographic evaluation was done in a blinded manner by two experienced radiologists, and in the event of contradictory results, a third evaluation was requested from another radiologist. Different degrees of fatty infiltration were considered: (a) light, when an increase was observed in echogenicity and hepatomegaly; (b) moderate, when sound attenuation was added; and (c) severe, when the walls of portal vessels and diaphragm were not visible ${ }^{31}$. Finally, the intraoperator reliability of NAFLD measurements was excellent for three operators, with intraclass correlation coefficient (ICC) of 0.88 ( $95 \%$ confidence interval [Cl]: 0.90-0.87), and inter-operator reliability was good, with ICC of 0.74 (95\% Cl: 0.78-0.70).

\section{Ethical considerations}

The study was approved by the Institutional Committee for Bioethics in Research of the University of Guanajuato (CIBIUG) (CIBIUG-P03-2016), and if both the child and the parent or tutor agreed to participate, they signed informed consent.

\section{Statistical analysis}

Descriptive statistics for data with a normal distribution are presented as mean and standard deviation and the data without normal distribution as median and ranges. A Student's t-test or a Mann-Whitney $U$-test was used for the difference between groups. For the differences between the degrees of NAFLD, an analysis of variance or Kruskal-Wallis test with a post hoc Tukey test was performed, and to carry out the statistical analysis according to the degree of hepatic steatosis, the children with moderate and severe NAFLD were grouped together, since the latter group only had nine children. A Spearman correlation test was used to determine the association between variables. In addition, a multiple regression analysis using the IGFBP-1 as a dependent variable and the significant variables from the correlation analysis as regressors were used. Listwise deletion of missing data was used for the multiple regression analysis. With respect to the ultrasonographic diagnosis of NAFLD, inter- and intra-observer variability was calculated using an ICC. The software Statistica 7.0 for Windows (StatSoft, Tucson, AZ) was used for all the analyses, and a value of $p<0.05$ was considered as significant.

\section{RESULTS}

A total of 83 children were studied with a mean age of $9.2 \pm 1.3$ years; $48.2 \%$ were male and $51.8 \%$ were female. About $93 \%$ of the girls presented IR, and $72.1 \%$ had a TG/HDL-C index $>2$. The main contributor to fructose intake was the sugar-sweetened beverages group, with $42.75 \pm 19.72 \mathrm{~g} /$ day; it was 
Table 1. Comparison of variables between the female and male gender

\begin{tabular}{|c|c|c|c|c|}
\hline \multirow[t]{2}{*}{ Variable } & \multicolumn{2}{|c|}{ Gender } & \multirow{2}{*}{$\begin{array}{l}\text { Value } \\
t / Z^{*}\end{array}$} & \multirow[t]{2}{*}{$\mathrm{p}$} \\
\hline & Male $(n=40)$ & Female $(n=43)$ & & \\
\hline Age (years)* & $9(6-11)$ & $9(6-11)$ & 0.59 & 0.55 \\
\hline $\operatorname{BMI}\left(\mathrm{Kg} / \mathrm{m}^{2}\right)$ & $26.2 \pm 2.5$ & $26.9 \pm 2.5$ & 1.28 & 0.20 \\
\hline Waist circumference $(\mathrm{cm})$ & $84.9 \pm 7.2$ & $90.0 \pm 7.4$ & 3.16 & 0.002 \\
\hline $\begin{array}{l}\text { Systolic blood pressure } \\
(\mathrm{mmHg})^{*}\end{array}$ & $95(80-115)$ & $90(80-120)$ & 0.11 & 0.91 \\
\hline $\begin{array}{l}\text { Diastolic blood pressure } \\
(\mathrm{mmHg})^{*}\end{array}$ & $60(50-80)$ & $60(50-85)$ & 0.73 & 0.47 \\
\hline \multicolumn{5}{|l|}{ Metabolic Variables } \\
\hline Triglycerides (mmol/L) & $1.44 \pm 0.47$ & $1.77 \pm 0.64$ & 2.7 & 0.009 \\
\hline Total-Cholesterol (mmol/L) & $4.17 \pm 0.66$ & $4.37 \pm 0.70$ & 1.29 & 0.20 \\
\hline $\mathrm{HDL}-\mathrm{C}(\mathrm{mmol} / \mathrm{L})$ & $1.46 \pm 0.21$ & $1.44 \pm 0.19$ & -0.56 & 0.58 \\
\hline VLDL $(\mathrm{mmol} / \mathrm{L})$ & $0.65 \pm 0.22$ & $0.8 \pm 0.3$ & 2.58 & 0.01 \\
\hline $\mathrm{LDL}(\mathrm{mmol} / \mathrm{L})$ & $2.0 \pm 0.53$ & $2.12 \pm 0.67$ & 0.89 & 0.37 \\
\hline Glucose $(\mathrm{mmol} / \mathrm{L})$ & $4.97 \pm 0.52$ & $4.94 \pm 0.50$ & -0.28 & 0.78 \\
\hline Insulin $(\mu \mathrm{IU} / \mathrm{mL})^{*}$ & $1.55(0.60-5.04)$ & $2.41(0.81-5.01)$ & 4.65 & 0.00001 \\
\hline HOMA-IR* & $2.3(0.9-8.2)$ & $3.7(1.1-8.5)$ & 4.46 & 0.00001 \\
\hline IGFBP-1 (ng/ml)* & $3.71(0.16-23.9)$ & $0.91(0.06-8.81)$ & -3.82 & 0.0001 \\
\hline $\begin{array}{l}\text { Triglyceride/HDL-C } \\
\text { index }\end{array}$ & $2.3 \pm 0.83$ & $2.9 \pm 1.2$ & 2.57 & 0.012 \\
\hline \multicolumn{5}{|l|}{ Dietetic Variables } \\
\hline Energy (Kcal/day) & $2315.6 \pm 539.0$ & $2174.5 \pm 479.1$ & -1.26 & 0.21 \\
\hline Protein (g/day) & $82.3 \pm 20.2$ & $78.0 \pm 16.9$ & -1.03 & 0.30 \\
\hline Lipids (g/day) & $86.2 \pm 25.6$ & $74.1 \pm 20.4$ & -2.39 & 0.019 \\
\hline Carbohydrates (g/day) & $310.7 \pm 71.3$ & $306.6 \pm 77.1$ & -0.25 & 0.80 \\
\hline Total fructose (g/day) & $61.8 \pm 19.9$ & $65.5 \pm 21.9$ & 0.82 & 0.41 \\
\hline Fructose Density (g/Kcal) & $0.027 \pm 0.007$ & $0.03 \pm 0.006$ & -2.07 & 0.042 \\
\hline
\end{tabular}

The variables with normal distribution are presented as mean \pm SD and the variables that did not follow normal distribution *were reported as median (range). BMI: body mass index, HOMA-IR: homeostatic model assessment of insulin resistance, IGFBP-1: insulin-like growth factor binding protein-1, HDL-C: high-density lipoprotein cholesterol, VLDL: very low-density lipoprotein.

followed by the sugar-sweetened foods group, with $14.56 \pm 9.39 \mathrm{~g} /$ day; the fruit group, with $4.69 \pm 5.52$ $\mathrm{g} /$ day; and finally, the vegetables and natural juices groups, with $<1.0 \mathrm{~g} /$ day.

Table 1 shows a comparison by gender for general and metabolic characteristics; the girls showed greater waist circumference $(p=0.002)$, TGs $(p=0.009)$,
VLDL $(p=0.01)$, HOMA-IR $(p=0.00001)$, and TG/ HDL-C index ( $p=0.012)$, and they had lower IGFBP-1 levels $(p=0.0001)$. No significant differences were found in fructose intake from the food groups analyzed (results not shown).

Table 2 shows the comparison of metabolic variables according to low or high IGFBP-1 levels. The group 
Table 2. Comparison of variables according to the low or high serum level of IGFBP-1

\begin{tabular}{|c|c|c|c|c|}
\hline \multirow[t]{2}{*}{ Variable } & \multicolumn{2}{|c|}{ IGFBP-1 } & \multirow{2}{*}{$\begin{array}{l}\text { Value } \\
\text { t/Z* }\end{array}$} & \multirow[t]{2}{*}{$\mathrm{p}$} \\
\hline & $\begin{array}{l}\text { Low }(<6.66) \\
\quad(n=51)\end{array}$ & $\begin{array}{l}\text { High }(\geq 6.67) \\
\quad(n=17)\end{array}$ & & \\
\hline Age (years)* & $10(6-11)$ & $8.0(6-11)$ & 2.66 & 0.008 \\
\hline $\mathrm{BMI}\left(\mathrm{Kg} / \mathrm{m}^{2}\right)$ & $27.2 \pm 2.4$ & $24.3 \pm 1.5$ & 4.62 & 0.00002 \\
\hline Waist circumference $(\mathrm{cm})$ & $89.6 \pm 6.9$ & $80.4 \pm 4.8$ & 5.09 & 0.000003 \\
\hline $\begin{array}{l}\text { Systolic blood pressure } \\
(\mathrm{mmHg})^{*}\end{array}$ & $95(80-120)$ & $90.0(80-105)$ & 1.52 & 0.12 \\
\hline $\begin{array}{l}\text { Diastolic blood pressure } \\
\quad(\mathrm{mmHg})^{*}\end{array}$ & $60.0(50-85)$ & $60.0(50-80)$ & 1.49 & 0.13 \\
\hline \multicolumn{5}{|l|}{ Metabolic variables } \\
\hline Triglycerides (mmol/L) & $1.63 \pm 0.65$ & $1.48 \pm 0.53$ & 0.86 & 0.39 \\
\hline Total-Cholesterol (mmol/L) & $4.27 \pm 0.72$ & $4.32 \pm 0.56$ & -0.27 & 0.79 \\
\hline $\mathrm{HDL}-\mathrm{C}(\mathrm{mmol} / \mathrm{L})$ & $1.45 \pm 0.21$ & $1.45 \pm 0.21$ & -0.11 & 0.90 \\
\hline VLDL $(\mathrm{mmol} / \mathrm{L})$ & $0.73 \pm 0.3$ & $0.67 \pm 0.24$ & 0.86 & 0.39 \\
\hline LDL (mmol/L) & $2.08 \pm 0.57$ & $2.02 \pm 0.55$ & -0.36 & 0.72 \\
\hline Glucose $(\mathrm{mmol} / \mathrm{L})$ & $4.96 \pm 0.48$ & $4.92 \pm 0.49$ & 0.22 & 0.82 \\
\hline Insulin $(\mu \mathrm{lU} / \mathrm{mL})^{*}$ & $2.06(0.94-5.01)$ & $0.99(0.6-2.06)$ & 4.95 & 0.000001 \\
\hline HOMA-IR * & $3.0(1.1-8.4)$ & $1.5(0.9-3.0)$ & 4.77 & 0.000002 \\
\hline $\begin{array}{l}\text { Triglyceride/HDL-C } \\
\text { index }\end{array}$ & $2.6 \pm 1.2$ & $2.4 \pm 0.95$ & 0.80 & 0.43 \\
\hline \multicolumn{5}{|l|}{ Dietetic variables } \\
\hline Energy (Kcal/day) & $2321.4 \pm 508.1$ & $1963.1 \pm 452.2$ & 2.58 & 0.012 \\
\hline Protein (g/day) & $80.6 \pm 18.5$ & $73.3 \pm 17.5$ & 1.42 & 0.16 \\
\hline Lipids (g/day) & $82.5 \pm 23.4$ & $70.7 \pm 21.6$ & 1.84 & 0.07 \\
\hline Carbohydrates (g/day) & $322.6 \pm 75.8$ & $264.3 \pm 58.5$ & 2.89 & 0.0051 \\
\hline Total fructose (g/day) & $67.5 \pm 23.1$ & $53.4 \pm 15.4$ & 2.34 & 0.022 \\
\hline Fructose Density (g/Kcal) & $0.029 \pm 0.006$ & $0.028 \pm 0.008$ & 0.47 & 0.641 \\
\hline
\end{tabular}

The variables with normal distribution are presented as mean \pm SD and the variables that did not follow normal distribution * were reported as median (range). BMI: body mass index, HOMA-IR: homeostatic model assessment of insulin resistance, IGFBP-1: insulin-like growth factor binding protein-1, HDL-C: high-density lipoprotein cholesterol, VLDL: very low-density lipoprotein, LDL: low-density lipoprotein.

with low IGFPB-1 was older $(p=0.008)$ and had higher BMI $(p=0.00002)$ and waist circumference $(p<$ $0.0001)$, as well as higher HOMA-IR ( $p<0.0001)$. In relation to dietary variables, a higher energy consumption $(p=0.012)$, carbohydrates $(p=0.051)$ and total fructose intake $(p=0.022)$ were found in the group with low IGFPB-1. No significant differences were found in fructose intake from the food groups analyzed (results not shown).

In the total group, $81 \%$ had NAFLD in its different levels (light $34 \%$ and moderate/severe $47 \%$ ). The group with moderate/severe NAFLD had higher BMI $(p=0.009)$, waist circumference $(p=0.046)$, insulin 
Figure 1. Comparison of fructose consumption according to the non-alcoholic fatty liver disease (NAFLD) degree. (1): none; (2): light; (3): moderate and severe NAFLD. NAFLD: non-alcoholic fatty liver disease.

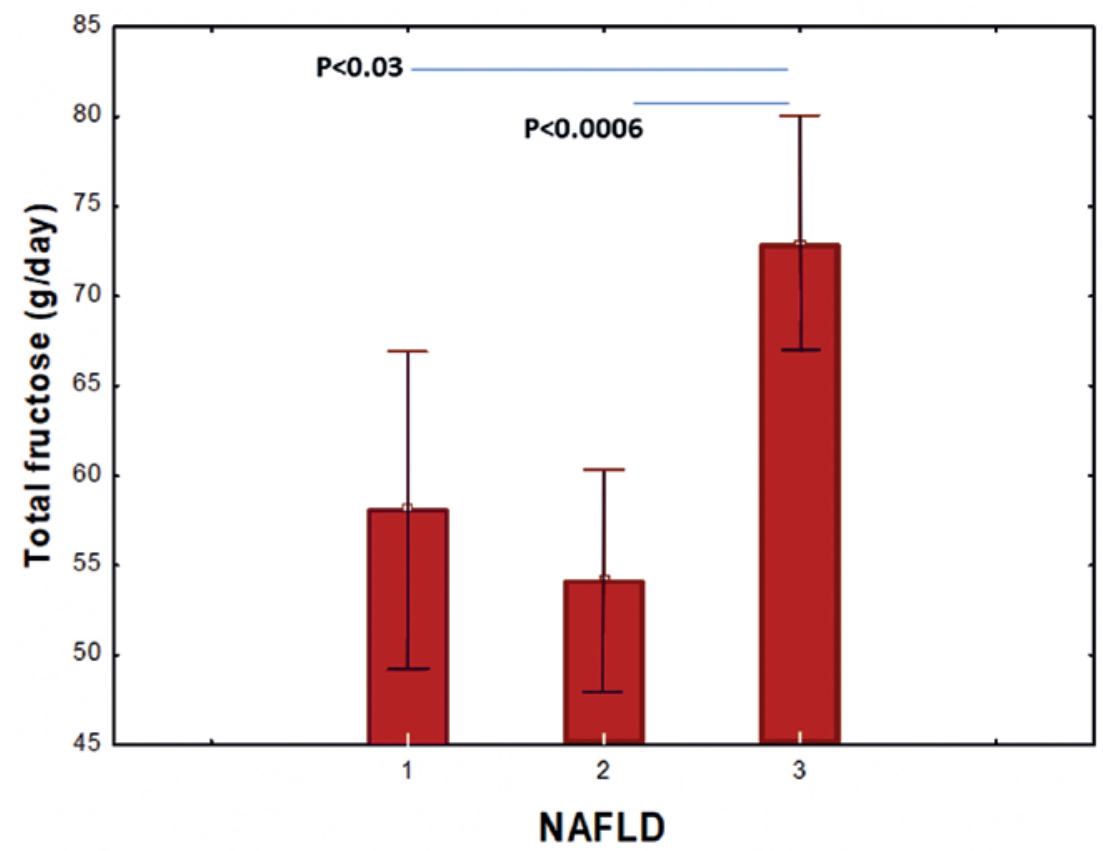

$(p=0.022)$, HOMA-IR $(p=0.036)$, carbohydrates intake $(p=0.005)$, total fructose intake $(p=0.001)$ (Fig. 1), and higher fructose intake from sugar sweetened beverages $(p=0.007)$. In this group, we also found lower levels of IGFBP-1, but these were not statistically significant (Table 3 ).

Negative correlations were found between IGFBP-1 and BMI $(r=-0.42 ; p=0.02), \operatorname{HOMA}-\mathrm{IR}(r=-0.61$; $p=0.002)$, and total fructose intake $(r=-0.25$; $\mathrm{p}=0.03)$.

The multiple regression analysis is presented in Table 4: IGFBP-1 was found to be associated with BMI, HOMA-IR, and total fructose intake $\left(R^{2}=0.41\right.$; $F=10.75 p<0.0001$ ), and this association persisted after adjustment by gender $\left(R^{2}=0.11\right.$; $\mathrm{F}=10.75 \mathrm{p}<0.0001$ ).

\section{DISCUSSION}

In Mexico, obesity is an important public health problem. The National Health and Nutrition Survey 2016 reported that the combined prevalence of overweight and obesity in children between 5 and 11 years was
$33.2 \%$. The obesity prevalence in girls was $12.2 \%$ and $18 \%$ in boys. In the past decades, high fructose intake has been associated with increased risk of obesity development and the consequent metabolic and inflammatory diseases ${ }^{3,32}$. Liver function is particularly vulnerable to an increasing fructose intake since this organ is responsible for approximately $90 \%$ of the total metabolism of this sugar ${ }^{33}$. The liver has also been found to be the main site of production of IGFBP-1 in humans, a marker of hepatic IR. However, few studies related to these markers have been conducted in children and none, to the best of our knowledge that evaluates hepatic IR, NAFLD, and fructose consumption in children with obesity. In this study, we evaluated school-age children and found that in the group with low levels of IGFBP-1, the children showed higher levels of IR and HOMA-IR, and IGFBP-1 showed a negative association with HOMA-IR. These results suggest that higher hepatic IR is present with higher whole IR. Similar results have been found by other authors in elderly men ${ }^{18}$ and nondiabetic patients on peritoneal dialysis ${ }^{34}$. An explanation for these results may be found in recent studies that proposed that IGFBP- 1 promotes the regeneration of $\beta$-cells ${ }^{15}$, reestablishing the pancreatic function while the total IR persists or worsens. Reports from animal studies 
Table 3. Comparison of variables according to the NAFLD degree

\begin{tabular}{|c|c|c|c|c|c|}
\hline Variable & $\begin{array}{l}\text { Normal } \\
(n=16)\end{array}$ & $\begin{array}{c}\text { Mild } \\
(n=28)\end{array}$ & $\begin{array}{l}\text { Moderate/Severe } \\
\quad(n=39)\end{array}$ & $\mathrm{F} / \mathrm{H}^{*}$ & $\mathrm{p}$ \\
\hline Age (years)* & $8.5(6-11)$ & $9.0(6-11)$ & $10(7-11)$ & 3.7 & 0.15 \\
\hline $\mathrm{BMI}(\mathrm{Kg} / \mathrm{m} 2)$ & $25.7 \pm 1.9$ & $25.9 \pm 2.5$ & $27.4 \pm 2.4$ & 4.1 & $0.009^{a, b}$ \\
\hline $\begin{array}{l}\text { Waist circumference } \\
(\mathrm{cm})\end{array}$ & $84.4 \pm 6.9$ & $86.2 \pm 7.8$ & $89.9 \pm 7.3$ & 2.8 & $0.046^{c}$ \\
\hline $\begin{array}{l}\text { Systolic blood } \\
\text { pressure }(\mathrm{mmHg})^{*}\end{array}$ & $90(80-110)$ & $90(80-110)$ & $90(85-120)$ & 3.8 & 0.49 \\
\hline $\begin{array}{l}\text { Diastolic blood } \\
\text { pressure }(\mathrm{mmHg})^{*}\end{array}$ & $60(50-75)$ & $60(50-75)$ & $60(50-85)$ & 4.6 & 0.09 \\
\hline $\begin{array}{l}\text { Triglycerides } \\
(\mathrm{mmol} / \mathrm{L})\end{array}$ & $1.49 \pm 0.61$ & $1.64 \pm 0.72$ & $1.64 \pm 0.47$ & 1.1 & 0.35 \\
\hline $\begin{array}{l}\text { Total-cholesterol } \\
(\mathrm{mmol} / \mathrm{L})\end{array}$ & $3.99 \pm 0.50$ & $4.32 \pm 0.63$ & $4.35 \pm 0.77$ & 1.9 & 0.12 \\
\hline $\mathrm{HDL}-\mathrm{C}(\mathrm{mmol} / \mathrm{L})$ & $1.36 \pm 0.22$ & $1.46 \pm 0.19$ & $1.47 \pm 0.20$ & 1.6 & 0.19 \\
\hline VLDL $(\mathrm{mmol} / \mathrm{L})$ & $0.67 \pm 0.28$ & $0.75 \pm 0.33$ & $0.75 \pm 0.22$ & 0.41 & 0.66 \\
\hline LDL (mmol/L) & $1.79 \pm 0.5$ & $2.1 \pm 0.56$ & $2.14 \pm 0.66$ & 2.07 & 0.13 \\
\hline $\begin{array}{l}\text { Glucose } \\
(\mathrm{mmol} / \mathrm{L})\end{array}$ & $4.87 \pm 0.52$ & $5.00 \pm 0.48$ & $4.96 \pm 0.53$ & 0.5 & 0.68 \\
\hline Insulin $(\mu \mathrm{lU} / \mathrm{mL})^{*}$ & $1.28(0.60-5.01)$ & $1.86(0.76-4.32)$ & $2.03(0.81-5.04)$ & 7.7 & 0.022 \\
\hline HOMA-IR* & $1.9(0.90-7.8)$ & $2.9(1.20-6.8)$ & $3.0(1.2-8.5)$ & 6.6 & $0.036^{d}$ \\
\hline IGFBP-1 (ng/ml)* & $2.6(0.16-18.6)$ & $2.5(0.6-15.7)$ & $1.5(0.11-23.9)$ & 1.63 & 0.44 \\
\hline $\begin{array}{l}\text { Triglyceride/HDL-C } \\
\text { index }\end{array}$ & $2.6 \pm 1.2$ & $2.6 \pm 1.2$ & $2.6 \pm 0.9$ & 0.5 & 0.67 \\
\hline Energy (Kcal/day) & $2110 \pm 424$ & $2077 \pm 452$ & $2416 \pm 537$ & 3.9 & $0.012^{\mathrm{e}}$ \\
\hline Protein (g/day) & $78 \pm 20$ & $76 \pm 16$ & $84 \pm 19$ & 1.9 & 0.12 \\
\hline Lipids (g/day) & $72 \pm 20$ & $76 \pm 20$ & $87 \pm 26$ & 2.1 & 0.10 \\
\hline $\begin{array}{l}\text { Carbohydrates } \\
\text { (g/day) }\end{array}$ & $297 \pm 74$ & $281 \pm 70$ & $333 \pm 70$ & 4.7 & $0.005^{f}$ \\
\hline $\begin{array}{l}\text { Total fructose } \\
\text { (g/day) }\end{array}$ & $58 \pm 16$ & $54 \pm 16$ & $73 \pm 22$ & 5.7 & $0.0014^{\mathrm{g}}$ \\
\hline $\begin{array}{l}\text { Fructose Density } \\
\text { (g/Kcal) }\end{array}$ & $0.028 \pm 0.006$ & $0.026 \pm 0.007$ & $0.031 \pm 0.007$ & 2.4 & 0.07 \\
\hline \multicolumn{6}{|l|}{ Food groups } \\
\hline $\begin{array}{l}\text { Vegetables } \\
\text { (g/day) }\end{array}$ & $0.78(0-5.23)$ & $0.37(0-1.89)$ & $0.54(0-1.74)$ & 1.4 & 0.16 \\
\hline Fruit (g/day) & $5.13(0-34.8)$ & $5.41(0-17.4)$ & $6.67(0-27.1)$ & 0.3 & 0.76 \\
\hline $\begin{array}{l}\text { 100\% fruit juices } \\
\text { (g/day) }\end{array}$ & $1.16(0-10.93)$ & $1.78(0-21.87)$ & $1.28(0-32.8)$ & -0.8 & 0.45 \\
\hline $\begin{array}{l}\text { Sugar sweetened } \\
\text { beverages (g/day) }\end{array}$ & $43.5 \pm 29.8$ & $38.1 \pm 16.5$ & $54.9 \pm 20.5$ & 5.32 & $0.007^{h}$ \\
\hline $\begin{array}{l}\text { Sugar sweetened } \\
\text { foods (g/day) }\end{array}$ & $26.2 \pm 18.2$ & $24.7 \pm 18.9$ & $26.6 \pm 17.0$ & 0.09 & 0.91 \\
\hline
\end{tabular}

The variables with normal distribution are presented as mean \pm SD and the variables that did not follow normal distribution * were reported as median (ranges). Non-alcoholic fatty liver disease (NAFLD). Significantly differences a: None versus moderate and severe, $p<0.041$,

b: Mild versus moderate and severe, $p<0.032$, c: None versus moderate and severe, $p<0.038$, d: None versus moderate and severe, $p<0.029$,

e: Mild versus moderate and severe, $p<0.02$, f: Slight versus moderate and severe, $p<0.009$, g: None versus moderate and severe, $p<0.031$,

h: Slight versus moderate and severe, $\mathrm{p}<0.006$. BMI: body mass index, HOMA-IR: homeostatic model assessment of insulin resistance, IGFBP-1: insulin-like growth factor binding protein-1, HDL-C: high-density lipoprotein cholesterol, VLDL: very low-density lipoprotein, LDL: low-density lipoprotein. 
Table 4. Association of the IGFBP-1 serum levels

\begin{tabular}{lllll}
\hline Dependent variable & \multicolumn{1}{c}{ Independent variables } & Beta $\pm S E$ & $t$ & $p$ \\
\hline$R=0.64 ; \mathrm{R}^{2}=0.41 ; \mathrm{F}=$ & $10.75 ; \mathrm{p}<0.00001$ & & & \\
IGFBP-1 $(\mathrm{n}=68)$ & BMI & $-0.57 \pm 0.22$ & -2.55 & 0.013 \\
& HOMA-IR & $-0.67 \pm 0.33$ & -2.02 & 0.047 \\
& Fructose consumption & $-0.05 \pm 0.02$ & -2.05 & 0.044 \\
& Gender & $-2.9 \pm 1.12$ & -2.60 & 0.012 \\
\hline
\end{tabular}

BMI: body mass index, HOMA-IR: homeostatic model assessment of insulin resistance, IGFBP-1: insulin-like growth factor binding protein-1.

indicate that obesity is associated with the suppression of the hepatic expression of mRNA of IGFBP-1 and a marked reduction of total concentrations of circulating IGFBP-135.

In our study, the group with lower levels of IGFBP-1 had a higher consumption of carbohydrates and total fructose, and in the multivariate analysis, IGFBP-1 showed a negative association with fructose consumption. In this sense, the liver is the primary site of de novo lipogenesis, the process by which fatty acids are synthesized from dietary precursors, predominantly carbohydrates ${ }^{36}$. Excessive fructose consumption may also have significant effects on lipid metabolism, contributing both to steatosis and to increased circulating TG levels by means of the inhibition of the enzyme carnitine palmitoyltransferase $1 \mathrm{~A}^{2}$. Changes in IGFBPs have been correlated with some metabolic syndrome (Mets) components, and predominantly with obesity ${ }^{37,38}$. Reinehr et al. ${ }^{22}$ found that IGFBP-1 correlated significantly with most of the Mets components (waist circumference, TGs, and HOMA-IR). Similar results were found in our group of children with obesity.

In our study group, $81 \%$ of the children showed NAFLD at levels (light $34 \%$, and moderate/severe $47 \%$ ) higher than those found in previous studies in our group $(42.5 \%)^{21}$. These children also had higher $\mathrm{BMI}$ and larger waist circumference; similar results were found in children from the general population and studies based on child obesity clinics, although the prevalence was lower ${ }^{39}$. The children with moderate/severe NAFLD showed higher HOMA-IR, which could be explained by reports that hyperinsulinemia leads to de novo lipogenesis, which is partially responsible for the accumulation of TGs in the hepatocytes and the development of steatosis ${ }^{40}$. However, the mechanisms by which high-fructose feeding cause's hyperinsulinemia and IR remain uncertain2. Fructose-induced steatosis may contribute to hepatic IR through increased hepatic diacylglycerol accumulation, protein kinase $\mathrm{C}$ activation, and impairment of insulin-mediated Akt2 activation ${ }^{41,42}$. However, whether steatosis itself can cause hepatic IR remains controversial ${ }^{43,44}$. In our study, higher consumption of carbohydrates and fructose observed in the group with moderate/severe NAFLD was similar to other studie ${ }^{56,10,45}$. High carbohydrates intake exceeding the energetic requirements and above the liver storage capacity in the form of glycogen, are converted into fatty acids to be stored as triacylglycerol, leading to NAFLD ${ }^{46}$. On the other hand, a metaanalysis indicated that consumption of fructose has more damaging effects on the hepatic insulin sensitivity than does the isocaloric consumption of carbohydrates ${ }^{4}$.

Likewise, Gugliucci ${ }^{47}$ state that approximately $90 \%$ of fructose intake is metabolized in the liver, while a large part of the glucose consumed passes through the liver and finds its way to skeletal muscle, where it degrades to $\mathrm{CO}_{2}, \mathrm{H}_{2} \mathrm{O}$, and adenosine triphosphate, and to the adipose tissue, where it is converted into phosphate glycerol for the synthesis of TGs and production of energy. Therefore, it is undeniable that in this multi-factorial pathology of NAFLD, elevated consumption of carbohydrates, especially fructose, is a major risk factor for its development.

A previous study in children by our group showed that the restriction of high-fructose foods with a decrease in caloric and carbohydrate intake, at 6 weeks 
induced a decrease of TG levels and hepatic steato$\mathrm{sis}^{48}$. In the present study, the group of children without steatosis and the group with mild steatosis had similar fructose intake; besides, they had similar metabolic and anthropometric characteristics. An explanation to these similarities could be that ultrasound is not sensitive enough to detect mild states of steatosis ${ }^{49}$.

It is important to highlight that our results show that girls have higher levels of TGs, HOMA-IR, I-TG/HDL, and lower IGFBP-1; all of them considered cardiovascular risk factors. A possible explanation is that girls had higher fructose consumption, which contributed to the development of hepatic IR, total IR, and higher TGs which could put them at higher risk of developing cardiometabolic diseases in early adulthood; thus, it is important to evaluate all of these risk factors from an early age.

This study had several weaknesses. First, the small sample size and that only 68 samples of IGFBP-1 were processed due to insufficient serum; also, the transversal nature of the study which did not allow us to evaluate causality; and finally, the use of ultrasound as a diagnostic tool for steatosis. Ultrasound detects fatty liver disease in patients with moderate and high-fat content but is limited in patients with low-fat content ${ }^{49}$. Furthermore, conventional ultrasound signs may be operator-dependent and subjective, although the intra- and inter-observer agreement in our study was good to excellent.

The group with lower levels of IGFBP-1 (marker of hepatic IR) was associated with BMI, HOMA-IR, and fructose consumption after adjustment by gender; the group with higher severity of NAFLD showed higher HOMA-IR and fructose consumption, and the metabolic alterations were more evident in females (higher TGs, HOMA-IR, and lower IGFBP-1). These results support the importance to evaluate children to prevent the development of chronic diseases.

\section{ACKNOWLEDGMENTS}

This study was supported by the CONACYT (GTO2012-C03-195255) and the University of Guanajuato (DAIP-2015) grants.

\section{REFERENCES}

1. Swinburn BA, Sacks G, Hall KD, McPherson K, Finegood DT, Moodie ML, et al. The global obesity pandemic: shaped by global drivers and local environments. Lancet. 2011;378:804-14.

2. Hannou SA, Haslam DE, McKeown NM, Herman MA. Fructose metabolism and metabolic disease. J Clin Invest. 2018;128: 545-55.

3. Bray GA, Popkin BM. Dietary sugar and body weight: have we reached a crisis in the epidemic of obesity and diabetes? Health be damned! Pour on the sugar. Diabetes Care. 2014;37:950-6.

4. Ter Horst KW, Schene MR, Holman R, Romijn JA, Serlie MJ. Effect of fructose consumption on insulin sensitivity in nondiabetic subjects: a systematic review and meta-analysis of diet-intervention trials. Am J Clin Nutr. 2016;104:1562-76.

5. Lim JS, Mietus-Snyder M, Valente A, Schwarz JM, Lustig RH. The role of fructose in the pathogenesis of NAFLD and the metabolic syndrome. Nat Rev Gastroenterol Hepatol. 2010; 7:251-64.

6. Diraison F, Yankah V, Letexier D, Dusserre E, Jones P, Beylot M, et al. Differences in the regulation of adipose tissue and liver lipogenesis by carbohydrates in humans. J Lipid Res. 2003; 44:846-53.

7. Herman MA, Samuel VT. The sweet path to metabolic demise: fructose and lipid synthesis. Trends Endocrinol Metab. 2016; 27:719-30.

8. Ter Horst KW, Serlie MJ. Fructose consumption, lipogenesis, and non-alcoholic fatty liver disease. Nutrients. 2017;9:e981.

9. Schwarz JM, Noworolski SM, Wen MJ, Dyachenko A, Prior JL, Weinberg ME, et al. Effect of a high-fructose weight-maintaining diet on lipogenesis and liver fat. J Clin Endocrinol Metab. 2015; 100:2434-42.

10. Vos MB, Lavine JE. Dietary fructose in nonalcoholic fatty liver disease. Hepatology. 2013;57:2525-31.

11. Aeberli I, Hochuli M, Gerber PA, Sze L, Murer SB, Tappy L, et al. Moderate amounts of fructose consumption impair insulin sensitivity in healthy young men: a randomized controlled trial. Diabetes Care. 2013;36:150-6.

12. Samuel VT, Shulman GI. Mechanisms for insulin resistance: common threads and missing links. Cell. 2012;148:852-71.

13. Borai A, Livingstone $C$, Heald $A H$, Oyindamola $Y$, Ferns $G$. Delta insulin-like growth factor binding protein-1 ( $\triangle \mathrm{IGFBP}-1)$ : a marker of hepatic insulin resistance? Ann Clin Biochem. 2014; 51:269-76.

14. Kotronen A, Lewitt $M$, Hall K, Brismar K, Yki-Järvinen $H$. Insulinlike growth factor binding protein 1 as a novel specific marker of hepatic insulin sensitivity. J Clin Endocrinol Metab. 2008; 93:4867-72

15. Lewitt MS, Hilding A, Ostenson CG, Efendic S, Brismar K, Hall K, et al. Insulin-like growth factor-binding protein-1 in the prediction and development of Type 2 diabetes in middle-aged Swedish men. Diabetologia. 2008;51:1135-45.

16. Lu J, Liu KC, Schulz N, Karampelias C, Charbord J, Hilding A, et al. IGFBP 1 increases $\beta$-cell regeneration by promoting $\alpha$ - to $\beta$-cell transdifferentiation. EMBO J. 2016;35:2026-44

17. Lewitt MS, Hilding A, Brismar K, Efendic S, Ostenson CG, Hall K, et al. IGF-binding protein 1 and abdominal obesity in the development of Type 2 diabetes in women. Eur J Endocrinol. 2010; 163:233-42.

18. Harrela M, Koistinen R, Tuomilehto J, Nissinen A, Seppälä M. Low serum insulin-like growth factor-binding protein-1 is associated with an unfavourable cardiovascular risk profile in elderly men. Ann Med. 2000;32:424-8.

19. Yu H, Rohan T. Role of the insulin-like growth factor family in cancer development and progression. J Natl Cancer Inst. 2000; 92:1472-89.

20. Graffigna M, Belli S, Larrañaga G, Fainboim H, Estepo C, Peres S, et al. La proteína transportadora del factor de crecimiento insulínico Tipo 1: Un nuevo marcador para la enfermedad hepática grasa no alcohólica? Acta Gastroenterol Latinoam. 2009; 39:30-7.

21. Ibarra-Reynoso Ldel R, Pisarchyk L, Pérez-Luque EL, Garay-Sevilla ME, Malacara JM. Whole-body and hepatic insulin resistance in obese children. PLoS One. 2014;9:e113576.

22. Reinehr T, Kleber M, Toschke AM, Woelfle J, Roth CL. Longitudinal association between IGFBP-1 levels and parameters of the metabolic syndrome in obese children before and after weight loss. Int J Pediatr Obes. 2011;6:236-43.

23. National Health and Nutrition Examination Survey. Anthropometry Procedures Manual; 2007. Available from: http://www.cdc. 
gov/nchs/data/nhanes/nhanes_07_08/manual_an.pdf. [Last accessed on 2019 Feb].

24. Cole TJ, Bellizzi MC, Flegal KM, Dietz WH. Establishing a standard definition for child overweight and obesity worldwide: international survey. BMJ. 2000;320:1240-3

25. National High Blood Pressure Education Program Working Group on High Blood Pressure in Children and Adolescents. The fourth report on the diagnosis, evaluation, and treatment of high blood pressure in children and adolescents. Pediatrics. 2004;114:555-76.

26. Matthews DR, Hosker JP, Rudenski AS, Naylor BA, Treacher DF, Turner RC, et al. Homeostasis model assessment: insulin resistance and beta-cell function from fasting plasma glucose and insulin concentrations in man. Diabetologia. 1985;28:412-9.

27. Aradillas-García C, Rodríguez-Morán M, Garay-Sevilla ME Malacara JM, Rascon-Pacheco RA, Guerrero-Romero F, et al. Distribution of the homeostasis model assessment of insulin resistance in Mexican children and adolescents. Eur J Endocrinol. 2012;166:301-6

28. Quijada Z, Paoli M, Zerpa Y, Camacho N, Cichetti R, Villarroel V, et al. The triglyceride/HDL-cholesterol ratio as a marker of cardiovascular risk in obese children; association with traditional and emergent risk factors. Pediatr Diabetes. 2008;9:464-71.

29. Yoo DY, Kang YS, Kwon EB, Yoo EG. The triglyceride-to-high density lipoprotein cholesterol ratio in overweight Korean children and adolescents. Ann Pediatr Endocrinol Metab. 2017; 22:158-63.

30. Pollock NK, Bundy V, Kanto W, Davis CL, Bernard PJ, Zhu H, et al. Greater fructose consumption is associated with cardiometabolic risk markers and visceral adiposity in adolescents. J Nutr. 2012;142:251-7.

31. Mittelstaedt CA. General Ultrasound. 1st ed. New York: Churchill Livingstone; 1992.

32. Campos VC, Tappy L. Physiological handling of dietary fructosecontaining sugars: implications for health. Int J Obes (Lond). 2016;40 Suppl 1:S6-11.

33. Tappy L, Lê KA. Metabolic effects of fructose and the worldwide increase in obesity. Physiol Rev. 2010;90:23-46.

34. Bernardo AP, Oliveira JC, Santos O, Carvalho MJ, Cabrita A, Rodrigues $A$, et al. Insulin resistance in nondiabetic peritoneal dialysis patients: associations with body composition, peritoneal transport, and peritoneal glucose absorption. Clin J Am Soc Nephrol. 2015;10:2205-12

35. Rajwani A, Ezzat V, Smith J, Yuldasheva NY, Duncan ER, Gage M, et al. Increasing circulating IGFBP1 levels improves insulin sensitivity, promotes nitric oxide production, lowers blood pressure, and protects against atherosclerosis. Diabetes. 2012;61:915-24.
36. Hellerstein MK Schwarz JM, Neese RA. Regulation of hepatic de novo lipogenesis in humans. Annu Rev Nutr 1996;16:523-57.

37. Aguirre GA, De Ita JR, de la Garza RG, Castilla-Cortazar I. Insulin-like growth factor-1 deficiency and metabolic syndrome. Transl Med. 2016;14:3.

38. Lewitt MS, Dent MS, Hall K. The insulin-like growth factor system in obesity, insulin resistance and Type 2 diabetes mellitus. J Clin Med. 2014:3:1561-74.

39. Anderson EL, Howe LD, Jones HE, Higgins JP, Lawlor DA, Fraser $A$, et al. The prevalence of non-alcoholic fatty liver disease in children and adolescents: a systematic review and meta-analysis. PLoS One. 2015;10:e0140908.

40. Browning JD, Horton JD. Molecular mediators of hepatic steatosis and liver injury. J Clin Invest. 2004;114:147-52.

41. Nagai Y, Yonemitsu S, Erion DM, Iwasaki T, Stark R, Weismann $D$, et al. The role of peroxisome proliferator-activated receptor gamma coactivator-1 beta in the pathogenesis of fructose-induced insulin resistance. Cell Metab. 2009;9:252-64.

42. Kumashiro N, Erion DM, Zhang D, Kahn M, Beddow SA, Chu $X$, et al. Cellular mechanism of insulin resistance in nonalcoholic fatty liver disease. Proc Natl Acad Sci U S A. 2011; 108:16381-5.

43. Benhamed F, Denechaud PD, Lemoine M, Robichon C, Moldes M Bertrand-Michel J, et al. The lipogenic transcription factor chREBP dissociates hepatic steatosis from insulin resistance in mice and humans. J Clin Invest. 2012;122:2176-94.

44. Farese RV Jr., Zechner R, Newgard CB, Walther TC. The problem of establishing relationships between hepatic steatosis and hepatic insulin resistance. Cell Metab. 2012;15:570-3.

45. Stanhope KL, Schwarz JM, Havel PJ. Adverse metabolic effects of dietary fructose: Results from the recent epidemiological clinical, and mechanistic studies. Curr Opin Lipidol. 2013;24:198206.

46. Cascales M. Lipogénesis de novo y Termogénesis. Available from: http://www.analesranf.com/index.php/mono/article/ download/1571/1655. [Last accessed on 2019 Feb].

47. Gugliucci A. Formation of fructose-mediated advanced glycation end products and their roles in metabolic and inflammatory diseases. Adv Nutr. 2017;8:54-62.

48. Ibarra-Reynoso LD, López-Lemus HL, Garay-Sevilla ME, Malacara JM. Effect of restriction of foods with high fructose corn syrup content on metabolic indices and fatty liver in obese children. Obes Facts. 2017;10:332-40.

49. Lee SS, Park SH, Kim HJ, Kim SY, Kim MY, Kim DY, et al. Noninvasive assessment of hepatic steatosis: prospective comparison of the accuracy of imaging examinations. J Hepatol. 2010; 52:579-85. 